\author{
MONIKA LECIŃSKA-RUCHNIEWICZ \\ Uniwersytet im. Adama Mickiewicza w Poznaniu \\ Wydział Neofilologii
}

\title{
RYS HISTORYCZNY TEATRU MUZYCZNEGO TAKARAZUKA - W POSZUKIWANIU NOWEGO „TEATRU NARODOWEGO”
}

\begin{abstract}
Niewątpliwie w teatrze muzycznym są spektakle wybitne i przeciętne, złożone i banalne, ale w dzisiejszych czasach trzeba zacząc od czegoś przeciętnego i banalnego. [...] Teraz, gdy uważa się, że najpierw należy wyjść do społeczeństwa z czymś pokroju operetki, ten uroczy żeński teatr muzyczny z pewnością również zyska uznanie.

Shōyō Tsubouchi ${ }^{1}$ o Teatrze Muzycznym Takarazuka, 1916 r. ${ }^{2}$
\end{abstract}

Świętujący w 2014 roku setną rocznicę powstania japoński Teatr Muzyczny Takarazuka (Takarazuka Kagekidan) to największa żeńska grupa teatralna w Japonii³. Jej historia sięga początku XX wieku, kiedy w wyniku zetknięcia się z kulturą Zachodu w Japonii rodził się nowy, nowoczesny teatr. Znalazło się w nim miejsce także dla rewii i musicalu, nieznanych wcześniej rozrywek.

Powstanie Teatru Muzycznego Takarazuka oraz jego rozwój od najwcześniejszych lat miały ścisły związek z powszechną modernizacją i westernizacją kraju. Jednym z przejawów ogólnego unowocześnienia była lokalna sieć Koleji Elektrycznej Minō Arima ${ }^{4}$, której dyrektorem był późniejszy założyciel zespołu, Ichizō Kobayashi (1873-1957). Umiejętnie wpisał się on w nową epokę, dostrzegając potrzebę stworzenia masowej rozrywki scenicznej adresowanej do przedstawicieli wszystkich klas społecznych, wykonywanej także przez kobiety. W Japonii, gdzie poszczególne gatunki teatru tradycyjnego były adresowane do reprezentantów określonej klasy5, a do chwili pojawienia się pierwszej zawodowej aktorki,

${ }^{1}$ Shōyō Tsubouchi (1859-1935) - tłumacz, dramatopisarz, reformator japońskiego dramatu i teatru współczesnego. Autor rozprawy Shōsetsu Shinzui (Istota powieści). Przełożył na język japoński wiele zachodnich sztuk (m.in. utwory Szekspira).

2 I. Kobayashi, Takarazuka manpitsu, Tōkyō 1980, s. 15-16.

${ }^{3}$ M. Sugawara, Yume no rebyūshi, Tōkyō 1996, s. 26.

${ }^{4}$ Minō Arima Denkikidō. Obecnie Kolej Hankyū (Hankyū Dentetsu).

${ }^{5}$ I. Kobayashi, Watakushi no yukikata, Tōkyō 2006, s. 201-202. Więcej na temat poszczególnych gatunków japońskiego teatru klasycznego zob. E. Żeromska, Japoński teatr klasyczny. Korzenie i metamorfozy, t. 2: Kabuki, burnaku, Warszawa 2009. 
Sady Yakko (1871-1946) ${ }^{6}$, na scenie występowali wyłącznie mężczyźni, oba pomysły Kobayashiego miały posmak rewolucyjny. Dzięki ich realizacji przyczynił się on do zmiany oblicza japońskiego teatru.

\section{Początki}

Wszystko zaczęło się w 1910 roku, kiedy po kilku nieudanych inwestycjach, mających na celu popularyzację nowo otwartych połączeń kolejowych w okolicy Osaki, Kobayashi skupił uwagę na tej, która łączyła metropolię ze stosunkowo mało jeszcze wówczas popularnym i niezbyt interesującym miasteczkiem Takarazuka. Nierentowność tego połączenia zmusiła biznesmena do podjęcia trudu zmierzającego do zwiększenia atrakcyjności nowej linii kolejowej. Uczynienie z Takarazuka lokalnego kurortu, a zarazem centrum kultury i rozrywki dla mieszkańców pobliskiej Osaki okazało się nadspodziewanym sukcesem.

W tym celu w 1911 roku otwarto w Takarazuka nowy ośrodek wypoczynkowy z gorącymi źródłami, który nazwano Takarazuka Shin ’onsen (Nowe Gorące Źródła w Takarazuka). Większość pomieszczeń tego kompleksu kontrastowała swym japońskim wystrojem z wnętrzem jednej z głównych budowli, Rajskiego Pawilonu, którą urządzono w modnym wówczas stylu europejskim, będącym połączeniem gotyku z secesją ${ }^{7}$. Goście mogli tam zrelaksować się przy muzyce fortepianowej, w otoczeniu marmurów i zachodnich mebli.

Rok później (1912) Kobayashi, zwolennik modernizacji, zaryzykował otwarcie tam pierwszego w Japonii krytego basenu. Jednak ten pomysł - nazbyt śmiały jak na ówczesne czasy - nie sprawdził się. Postanowił więc wybudować na terenie zamkniętej pływalni małą, prowizoryczną scenę z niewielką widownią. W pomieszczeniu tym początkowo organizowano różne wystawy, które mogłyby zainteresować kobiety. Szczególną popularnością cieszyły się ekspozycje obrazów i przedmiotów o tematyce nawiązującej do życia gospodyń domowych oraz targi ślubne i rodzinne. Największym sukcesem okazały się jednak, organizowane tam od 1913 roku, koncerty w wykonaniu młodych dziewcząt, które przyczyniały się do zacieśniania więzi świata sztuki ze światem biznesu i handlu. W tej amatorskiej działalności artystycznej Kobayashi dostrzegł szansę rozwiązania problemu nierentowności nowej linii kolejowej, a przy okazji przyczynienia się do zmodernizowania nieodpowiadającego na potrzeby ówczesnego widza teatru japońskiego. W tym samym roku Kobayashi, zainspirowany komercyjnym sukcesem stworzonego przez dyrekcję sieci luksusowych domów towarowych Mitsukoshi, Chłopięcego Chóru Mitsukoshi (Mitsukoshi Shōnen Ongakutai), powołał do życia Chór Takarazuka (Takarazuka Shōkatai) złożony z uzdolnionych wokalnie i artystycznie pracownic kurortu. Dodatkową zachętą do założenia żeńskiego zespołu była niewątpliwie, założona (1908) przez Sadę Yakko, działająca przy tokijskim Teatrze Cesarskim (Teikoku Gekijō) Cesarska Szkoła Aktorek (Teikoku Joyū Yōseisho), w której kształcono pierwsze w Japonii zawodowe aktorki ${ }^{8}$.

${ }^{6}$ Sadayakko Kawakami (u szczytu kariery znana jako Sada Yakko lub Sada) - gejsza, następnie żona kontrowersyjnego, japońskiego aktora Otojiro Kawakami. Była także pierwszą japońską aktorką od czasów, gdy w XVII wieku zabroniono w Japonii występować kobietom na scenie.

${ }^{7}$ K. Kawasaki, Takarazuka shōhishakai no supekutakuru, Tōkyō 1999, s. 23.

8 Zob. artykuł E. Żeromskiej Na pograniczu realizmu: kobieta i kobiecość w teatrze japońskim, Porównania 2016, nr 18, s. 239-256. 
Nauczycielem żeńskiego Chóru Takarazuka został Hiroshi Andō (1883-1967) - specjalista z dziedziny opery. Jego wypracowana wspólnie z Kobayashim wizjonerska koncepcja działalności tego zespołu zakładała wzbogacenie repertuaru o występy taneczne i teatralne, dzięki czemu bardzo szybko doprowadzili oni do przekształcenia kilkunastoosobowego chóru w Grupę Szkoleniową Żeńskiego Teatru Muzycznego Takarazuka (Takarazuka Shōjo Kageki Yōseikai) $)^{9}$ i zapewnili młodym artystkom zarówno zajęcia ze śpiewu, jak i z tańca oraz gry aktorskiej.

\section{Nowe idee}

Zakładając ten zespół, Kobayashi - miłośnik włoskiej opery i krytyk teatralny - kierował się chęcią stworzenia nowego, dostępnego i zrozumiałego dla wszystkich teatru narodowego, odpowiadającego potrzebom współczesnego społeczeństwa japońskiego ${ }^{10}$. Pierwszym krokiem w tym kierunku miała być nowa organizacja funkcjonowania teatru, oparta na zasadach odmiennych od tych, które obowiązywały w firmie producenckiej Shōchiku ${ }^{11}$, a pod względem artystycznym - opracowanie innej niż w tradycyjnych gatunkach teatru japońskiego, oryginalnej techniki gry aktorskiej ${ }^{12}$. Kobayashi miał ambicję stworzyć teatr stanowiący alternatywę dla japońskiej tradycji widowiskowej (kyūgeki), jak teatr $n \bar{o}$, farsy kyōgen, a zwłaszcza dla teatru kabuki, który choć w okresie Edo (1603-1868) był ulubioną atrakcją mieszczan, w połowie XIX wieku szybko zatracił kontakt ze zmieniającą się rzeczywistością i przekształcił w niezrozumiałą dla mas, elitarną rozrywkę wyższych klas społecznych $^{13}$.

Kobayashi nie zamierzał jednak polemizować, ani tym bardziej rywalizować, z silnie zakorzenionym w tradycji i historii Japonii teatrem klasycznym. Pragnął jedynie zapoznać społeczeństwo z nowym teatrem w stylu zachodnim. Był on bowiem zwolennikiem harmonijnego i rozważnego wzbogacenia japońskiej tradycji o takie elementy jak orkiestra grająca na europejskich instrumentach europejską muzykę czy wykonywany do jej akompaniamentu śpiew. W tym właśnie upatrywał szansy rozwoju japońskiej sztuki teatralnej jako rozrywki masowej (taishūgoraku ${ }^{14}$. Bez muzyki zachodniej nie wyobrażał sobie nowczesnego teatru japońskiego, którego główny nurt - jak twierdził - powinny stanowić rewia, opera i operetka ${ }^{15}$.

9 Obecna nazwa - Takarazuka Kagekidan (Teatr Muzyczny Takarazuka) - została teatrowi nadana dopiero w 1940 roku.

10 T. Tsuganesawa, Takarazuka Senryaku - Kobayashi Ichizō no seikatsubunkaron, Tōkyō 1991, s. 160-161.

11 Shōchiku - japońskie studio teatralno-filmowe. Początkowo skupione głównie wokół kabuki oraz innych japońskich teatrów klasycznych, później także współczesnych (do Shōchiku należą dwie największe, poza Takarazuką, japońskie rewie żeńskie: Shōchiku Kagekidan oraz Ōsaka Shōchiku Kagekidan). Obecnie Shōchiku jest także jedną z większych japońskich wytwórni filmowych.

12 T. Tsuganesawa, Takarazuka Senryaku..., op. cit., s. 160-161.

13 H. Watanabe, Takarazuka Kageki no henyō to Nihon kindai, Tōkyō 1999, s. 24-25.

14 T. Tsuganesawa, Takarazuka Senryaku..., op. cit., s. 159.

15 Ibidem, s 162-163. 
Kobayashi chętnie nawiązywał do teatru kabuki, co sprawiło, że z biegiem lat pojawiło się wiele mylnych poglądów na temat powodów, dla których stworzył swój żeński zespół rewiowy. Były to w większości opinie oparte na błędnym przekonaniu, że kierował się chęcią przeciwstawienia rodzimemu teatrowi klasycznemu, na którego scenę do dziś dopuszczani są wyłącznie mężczyźni. Tymczasem założyciel żeńskiej rewii odnosił się do gatunku teatralnego kabuki jako symbolu bogatej tradycji teatralnej Japonii. Hiroshi Watanabe pisze o tym następująco:

Kiedy [Kobayashi] mówił o teatrze muzycznym, niezmiennie odwoływał się do niego w kontekście kabuki zwanego „starym teatrem” [kyūgeki]. Uważał, że teatr muzyczny stwarza szansę zreformowania tego „starego teatru”. [Kobayashi] twierdził, że kabuki, niegdyś reprezentatywny japoński „teatr narodowy”, teraz - w nowych czasach - stał się daleki i niezrozumiały dla widza i, jeżeli nic się nie zmieni, będzie się tylko staczać ku upadkowi, aż ostatecznie zaniknie ${ }^{16}$.

Dla Kobayashiego kabuki było zatem nie tyle określeniem konkretnego gatunku teatru, co reprezentantem przestarzałego - jego zdaniem - japońskiego teatru klasycznego. Jednocześnie dostrzegał on potrzebę stworzenia nowego „teatru narodowego” (kokumingeki) odpowiadającego potrzebom ówczesnego, coraz bardziej demokratycznego społeczeństwa japońskiego. Teatr Muzyczny Takarazuka miał więc raczej stanowić alternatywę dla artystycznej konwencji teatru kabuki, a nie jego feministyczny odpowiednik, tym bardziej że decyzja o wyłącznie żeńskim składzie grupy była dziełem przypadku, rezultatem niespodziewanej popularności dziewcząt zabawiających gości gorących źródeł pokazami artystycznymi, a także ówczesnej mody na promowanie aktywności kobiet na scenie. Należy bowiem pamiętać, że w Japonii do połowy ery Meiji (1868-1912) wspólne występowanie na jednej scenie mężczyzn i kobiet było zasadniczo zabronione ${ }^{17}$. Zresztą na początku XX wieku Teatr Muzyczny Takarazuka nie był jedyną żeńską grupą artystyczną w Japonii. Na przykład w tokijskim domu towarowym Shirokiya od 1912 roku występowała Żeńska Grupa Muzyczna (Shōjo Ongakutai), a w 1917 roku Suzuki Yasuyoshi powołał w Tokio do życia Operę Asahi (Asahi Kagekidan), która, choć zatrudniała także kilku mężczyzn, została później przemianowana na Tokijską Operę Żeńską (Tōkyō Shōjo Kageki) ${ }^{18}$. Jak słusznie zauważa w swojej książce Hiroshi Watanabe, ,panowała wówczas moda na teatry żeńskie, dlategoTeatr Muzyczny Takarazuka nie był niczym niezwykłym"19.

Teatr Muzyczny Takarazuka rozpoczął oficjalną działalność w 1914 roku²0. Debiutował trzema spektaklami: Don Burako (Łubu dubu ${ }^{21}$ ), Ukare daruma (Wesoły daruma ${ }^{22}$ ) oraz Kochō (Motyl). Przedstawienia odbywały się na wspomnianej wcześniej, prowizorycznej

16 H. Watanabe, Takarazuka Kageki..., op. cit., s. 23.

17 K. Kawasaki, Takarazuka shōhishakai..., op. cit., s. 11.

${ }_{18}$ H. Watanabe, Takarazuka Kageki..., op. cit., s. 19-20.

19 Ibidem, s. 20.

${ }^{20}$ Wówczas funkcjonował pod nazwą Takarazuka Shōjo Kageki Yōseikai.

21 Sztuka muzyczna autorstwa Ueharu Kitamury, oparta na japońskiej przypowieści Momotaro. Tytuł wywodzi się od użytej w pierwszym zdaniu oryginalnego opowiadania onomatopei „don burako" oddającej turlanie się ciężkiego przedmiotu.

${ }^{22}$ Daruma - tradycyjna japońska lalka o bulwiastym kształcie, wielkich oczach, pozbawiona rąk i nóg. Jest karykaturalnym przedstawieniem Bodhidarmy - patriarchy chińskiego buddyzmu chan. 
scenie wybudowanej na terenie ośrodka rekreacyjnego Takarazuka Shin'onsen. Przez pierwsze lata działalności grupa wystawiała głównie krótkie sztuki o tematyce japońskiej, oparte na japońskich przypowieściach, legendach czy literaturze ${ }^{23}$.

\section{Szkoła Muzyczna Takarazuka}

Kobayashi, doskonały koneser teatralny i menadżer, zdawał sobie sprawę, że do odniesienia sukcesu niezbędny jest nie tylko ciekawy, oryginalny repertuar, lecz również odpowiedni system i warunki do profesjonalnego kształcenia zatrudnianych w teatrze artystek. Z jego inicjatywy 11 stycznia 1918 roku wprowadzono dla aktorek obowiązkowe zajęcia ze śpiewu, tańca oraz gry na instrumentach muzycznych, 6 stycznia 1919 roku natomiast, na mocy uzyskanej 28 grudnia 1918 roku zgody Ministerstwa Edukacji, Kobayashi ufundował prywatną szkołę o nazwie Takarazuka Ongaku Kageki Gakkō (Muzyczno-Operowa Szkoła Takarazuka) ${ }^{24}$ - w trosce o artystyczny rozwój występujących na scenie dziewcząt.

Kobayashi, mimo swej postępowości, bardzo wysoko cenił tradycyjne japońskie wartości społeczno-kulturowe. Dlatego do założonej przez siebie szkoły wprowadził surową, tradycyjną dyscyplinę. Nauka w tej placówce miała przygotowywać dziewczęta nie tylko do występowania na scenie, ale również do poprawnego funkcjonowania w społeczeństwie. Również dziś „Szkoła Muzyczna Takarazuka nie jest miejscem zdobywania jedynie niezbędnego do pracy na scenie teatru rewiowego wykształcenia muzycznego, tanecznego czy aktorskiego. Jest także miejscem kształtowania charakteru, rozwagi niezbędnej aktorce teatralnej oraz dobrych manier" 25 .

Obecnie nauka w Szkole Muzycznej Takarazuka podzielona jest na dwa roczne kursy, przygotowawczy (yoka) oraz właściwy (honka), podczas których adeptki doskonalą umiejętności muzyczne - praktyczne (śpiew, gra na różnych instrumentach) i teoretyczne (historia i teoria muzyki), taneczne (tańce japońskie i zachodnie, tradycyjne i nowoczesne) oraz aktorskie (sztuka recytacji, technika gry). Uczestniczą także w zajęciach z historii teatru i dramatu, kultury, wiedzy o świecie współczesnym i etykiety ${ }^{26}$. Przyszłym aktorkom wpaja się ponadto surowy system zasad obowiązujących w szkole i teatrze. Dziewczęta uczą się respektowania fundamentalnego dla japońskiego społeczeństwa systemu starszeństwa (jōkakankei), który dotyczy również relacji między uczennicami pierwszego (yokasei) i drugiego (honkasei) roku szkoły, a później także między młodszymi (kakyūsei) a starszymi (jōkyūsei) stażem aktorkami.

Kluczowe znaczenie dla całego życia zawodowego ma decyzja, czy dana uczennica będzie w przyszłości specjalizować się w rolach męskich (otokoyaku) czy żeńskich (musumeyaku). Od tego zależy ukierunkowanie edukacji uczennic od drugiego roku nauki

${ }^{23}$ S. Hosokawa, Shoki no Takarazuka Kageki bunkashi-otogigeki kara rebyū made, ed. B. Makita, http:// web.kyoto-inet.or.jp/people/vmakita/ezuka-speech.html (25.07.2015).

${ }^{24}$ Obecnie Takarazuka Ongaku Gakkō (Szkoła Muzyczna Takarazuka).

${ }_{25}$ K. Kobayashi, Prelude - Takarazuka Ongaku Gakkō dai 93ki Bunkasai, Takarazuka 2007, s. 4.

26 Y. Ueda, Takarazuka Ongaku Gakkō, Ōsaka 1976, s. 36. 
w szkole. Wówczas dokonuje się również wyboru pseudonimu artystycznego (geimei $)^{27}$, który przez cały okres kariery scenicznej będzie zastępować aktorce jej prawdziwe imię i nazwisko.

Uczennice mające w przyszłości odgrywać role żeńskie (musumeyaku), uczą się, jak stać się na scenie idealną kobietą. Poznają arkana kobiecości, czyli właściwy sposób mówienia, poruszania się, zasady savoir vivre oraz dbania o własny wygląd. W ramach zajęć wokalnych natomiast opanowują umiejętność śpiewania na wysokich tonach.

Dziewczęta, którym w udziale przypadło specjalizowanie się w emploi otokoyaku uczą się bycia idealnym mężczyzną. Ich zadaniem jest stworzenie na scenie przekonującej dla widzów iluzji. Dlatego uczennice honka ścinają krótko włosy, a poza szkołą noszą spodnie, koszule i garnitury. Kształcąc głos, uczą się go obniżać i modulować w taki sposób, by mimo to wciąż wydawał się naturalny. Opanowują też podstawy męskiego stylu bycia. Perfekcyjność w tym względzie osiągają zwykle dopiero po latach nauki i praktyki na scenie. W teatrze popularne jest powiedzenie otokoyaku jünen oznaczające, że do opanowania umiejętności przeistaczania się $\mathrm{w}$ postaci męskie potrzeba przynajmniej dziesięciu lat ${ }^{28}$.

Od początku widzowie doceniali dbałość o jak najwyższe standardy kształcenia zawodowego aktorek oraz poziomu artystycznego zespołu Takarazuka Kagekidan, a także troskę o nienaganną kulturę osobistą aktorek - na scenie i poza nią. Kobiety, mężczyźni, dorośli i dzieci thumnie chodzili na wszystkie kolejne przedstawienia, przyczyniając się w ten sposób do systematycznego wzrostu popularności zespołu.

Warto wspomnieć, że w 1919 roku po raz pierwszy postanowiono dopuścić mężczyzn na scenę Teatru Muzycznego Takarazuka. $Z$ tego powodu do Szkoły Teatru Muzycznego Takarazuka przyjęto ośmiu chłopców, którzy jednak ze względu na sprzeciw ze strony większości pracowników teatru oraz fanów, po dziesięciu miesiącach zostali ze szkoły usunięci ${ }^{29}$. Mimo to próby przeprowadzenia naboru wśród mężczyzn podjęto również po drugiej wojnie światowej (w grudniu 1945 roku, marcu 1946 roku oraz kwietniu 1947 $\mathrm{roku}^{30}$ ), ale nawet tym chłopcom, którzy ukończyli szkołę, zezwalano jedynie na występowanie w kage kōrasu (chór w tle), nigdy w charakterze solistów ${ }^{31}$. Ostatni nabór wśród dziewcząt i chłopców odbył się w 1953 roku, a w 1956 roku wprowadzono definitywny zakaz podchodzenia mężczyzn do egzaminów wstępnych do Takarazuka Ongaku Gakkōis

\section{Pierwsze sukcesy}

Stale rosnąca popularność wyłącznie żeńskiej rewii sprawiła, że prowizoryczna scena na terenie kurortu przestała odpowiadać wymaganiom zespołu. Potrzebna była nowa sie-

${ }^{27}$ K. Kobayashi, Prelude..., op. cit., s. 6.

${ }^{28}$ Kawasaki K., Takarazuka to iu yūtopia, Tōkyō 2005, s. 165.

${ }^{29}$ Yume wo egaite hanayaka ni Takarazuka Kageki 80 nenshi, Takarazuka 1994, s. 253-254.

${ }^{30}$ Yume wo egaite hanayaka, op. cit., s. 254.

${ }^{31}$ Często obecny w spektaklach śpiew chóralny w wykonaniu aktorek znajdujących się w tzw.: besshitsu, czyli pokoju umieszczonym za skrzydłem sceny, niewidocznym dla widzów.

${ }^{32}$ Y. Ueda, Takarazuka Ongaku..., op. cit., s. 11. 
dziba z większą, nowoczesną sceną i zmodernizowaną widownią w zachodnim stylu. Pierwszą przebudowę ukończono w marcu 1919 roku, a w październiku 1920 roku zastąpiono tradycyjne zashiki ${ }^{33}$ krzesłami. Jednocześnie dokonano podziału zespołu na dwie grupy - Grupę Kwiatów (Hanagumi) oraz Grupę Księżyca (Tsukigumi), które występowały naprzemiennie. Po roku tego typu praktyki, która okazała się wyśmienitym rozwiązaniem strategicznym, zwiększono liczbę wystawianych rocznie spektakli. Dzięki temu zespół szybko rozrósł się do takich rozmiarów, że w lipcu 1924 roku utworzono kolejną, trzecią grupę nazwaną Yukigumi (Grupa Śniegu). W rezultacie wzniesiono jeszcze jeden, większy budynek o nazwie Takarazuka Daigekijō (Wielki Teatr Takarazuka), który do dziś pozostaje główną siedzibą rewii ${ }^{34}$.

Kobayashi, przywiązując dużą wagę do wysokich walorów artystycznych, dostrzegał potrzebę poznawania świata przez pracowników zespołu. W celu umożliwienia im zdobywania doświadczenia za granicą utworzył fundusz stypendialny i na początku lat dwudziestych zaczął wysyłać swoich artystów do Ameryki i Europy. W 1926 roku w podróż służbową wyjechali między innymi: scenarzysta i reżyser Tatsuya Kishida (1892-1944), a w 1928 roku - reżyser i choreograf Tetsuzō Shirai (1900-1983). Po powrocie odegrali oni kluczową rolę w kształtowaniu kierunków rozwoju Teatru Muzycznego Takarazuka, a zwłaszcza jego repertuaru.

Tatsuya Kishida zasłynął jako autor pierwszej japońskiej rewii pt. Mon Pari (Mój Paryż). Opisał w niej własne, zdobyte podczas podróży po świecie doświadczenia. Inscenizacja tego utworu wiązała się jednak - poza nową techniką gry (w stylu zachodnim), kostiumami, tańcem i wielkimi kosztami - z koniecznością pokonania wielu problemów, z których do najtrudniejszych należała adaptacja przestarzałego zaplecza scenicznego, zwłaszcza mechanizacja maszynerii w celu umożliwienia dokonywania na przykład szybkich zmian dekoracji. Dzięki zaangażowaniu Kobayashiego i finansowemu wsparciu firmy Hankyū Dentetsu, 1 września 1927 roku odbyła się premiera pierwszej japońskiej rewii zatytułowanej Mon Pari - Waga Pari yo (Mon Paris - Mój Paryż ). Sukces przedstawienia był spektakularny. Japończycy, którzy dzięki tej rewii po raz pierwszy zobaczyli na scenie zmysłowe, europejskie tańce, jak na przykład kankan, wykonywane do muzyki granej na zachodnich instrumentach, w niezwykłych kostiumach ozdobionych barwnymi piórami, oniemieli z zachwytu. Bilety na wszystkie przedstawienia sprzedawano błyskawicznie.

Kolejnym przełomowym spektaklem w dziejach Teatru Muzycznego Takarazuka była wystawiana od 1 sierpnia 1930 roku inscenizacja sztuki Parizetto ( Paryżanka) autorstwa Tetsuzō Shirai, który dzięki niej zasłużył sobie na miano króla rewii (rebyū no ōsama). To nowatorskie widowisko wprowadziło Japonię w świat paryskiej rewii. Zaszokowało widzów nowymi środkami wyrazu, panującą na scenie swobodą obyczajową ${ }^{35}$, a także pożyczonymi z francuskich teatrów rewiowych wachlarzami czy ozdobnymi pióropuszami, a także kostiumami bogato zdobionymi cekinami i cyrkoniami. Z równą fascynacją japońscy widzowie odkrywali też nowy rodzaj makijażu, który był zdecydowanie dyskretniejszy

33 Tradycyjne japońskie siedziska na matach tatami.

34 Budynek Wielkiego Teatru Takarazuka był jeszcze kilkakrotnie modernizowany i przebudowywany. Ostateczną formę zyskał w 1995 roku.

35 T. Tsuganesawa, Takarazuka Senryaku..., op. cit., s. 58. 
i bardziej naturalny niż stosowany dotychczas shironuri (biały makijaż) ${ }^{36}$, wzorowany na makijażu charakterystycznym dla teatru kabuki ${ }^{37}$. Po Paryżance Shirai stworzył wiele nie mniej popularnych spektakli, a wśród nich między innymi pierwszy japoński musical Rōzu Pari (Różany Paryż, 1931).

O ile Kishidę uważa się za twórcę japońskiej rewii, o tyle Shirai postrzegany jest jako osoba, która ją wzbogaciła i udoskonaliła ${ }^{38}$. Dzisiaj można powiedzieć, że obaj wizjonerzy przyczynili się do przeistoczenia Chóru Takarazuka w Teatr Muzyczny Takarazuka i do nadania mu charakterystycznego stylu artystycznego, będącego połączeniem cech zachodniej rewii, musicalu oraz japońskiej tradycji teatralnej.

Sukces - balansujacych na pograniczu artyzmu i kiczu, sztuki wysokiej i rozrywki masowej - nowatorskich spektakli rewiowych Teatru Muzycznego Takarazuka zaowocował w 1934 roku otwarciem dodatkowej siedziby, tym razem w Tokio, oraz utworzeniem czwartej z kolei grupy o nazwie Hoshigumi (Grupa Gwiazd). Ostatnią z obecnie działających grup, Soragumi (Grupa Kosmosu), powołano do życia w 1998 roku.

Największym sukcesem japońskiej rewii z Takarazuka w początkowym okresie działalności było pierwsze zagraniczne tournée w 1938 roku. Zespół wystąpił łącznie w dwudziestu sześciu miastach Niemiec, Polski i Włoch. Od tamtej pory Teatr Muzyczny Takarazuka wielokrotnie gościł na scenach niemal całego świata, w krajach takich jak: USA, Kanada, Meksyk, Argentyna, Brazylia, Chiny, Korea Południowa, Birma, Malezja, Singapur, Tajlandia, Litwa, Rosja, Ukraina, Francja, Niemcy, Anglia.

\section{Westernizacja po drugiej wojnie światowej}

Systematyczne wzbogacanie repertuaru o zachodnie nowinki teatralne przyczyniało się do coraz wyraźniejszej westernizacji stylu przedstawień, których tematyka coraz rzadziej nawiązywała, przeciwnie niż w okresie początkowym istnienia zespołu, do rodzimych pieśni, baśni czy wątków literackich. Twórcy woleli czerpać inspirację z rewiowej, komediowej czy operetkowej tradycji Zachodu.

Po drugiej wojnie światowej repertuar zespołu poszerzono o inscenizacje utworów należących do kanonu literatury światowej. Znalazły się wśród nich między innymi spektakle inspirowane dziełami: Szekspira (Romeo i Julia, Sen nocy letniej, Wieczór trzech króli), Fiodora Dostojewskiego (Bracia Karamazow), Lwa Tołstoja (Wojna i pokój, Anna Karenina), Antona Czechowa (Mewa), Margaret Mitchell (Przeminęto z wiatrem), Ernesta Hemingwaya (Komu bije dzwon), Karola Dickensa (Opowieść o dwóch miastach), Scotta Fitzgeralda (Ostatni z wielkich), Ericha Marii Remarque'a (Luk triumfalny), Henry'ego Fieldinga (Historia życia Toma Jonesa, czyli dzieje podrzutka), Stendhala (Czerwone i czarne), Anthony'ego Hope'a (Więzień na zamku Zenda) czy Aleksandra Dumas (Człowiek w żelaznej masce, Hrabia Monte Christo).

\footnotetext{
${ }^{36}$ Makijaż polegający na pokrywaniu twarzy i dekoltu warstwą śnieżnobiałego pudru.

${ }^{37}$ O. Shima, Kobayashi Ichizō to sono bijogun, 70 nen no himitsu - Za Takarazuka, Tōkyō 1984, s. 99-100.

${ }^{38}$ Ibidem, s. 99.
} 
Oprócz dzieł literatury rodzimej i światowej w Teatrze Muzycznym Takarazuka wystawiano również utwory należące do nurtu kultury masowej, jak na przykład manga ${ }^{39}$ (m.in. Berusaiyu no bara [Róża Wersalu], Burakku Jakku [Black Jack]) czy gry komputerowe (Gyakuten saiban [Phoenix Wright]). To właśnie adaptacja japońskiego komiksu autorstwa Ryōko Ikedy pt. Róża Wersalu (Berusaiyu no bara) wystawiona po raz pierwszy w 1974 roku zapewniła zespołowi znaczny wzrost popularności. Róża Wersalu zyskała miano sztandarowego dzieła Teatru Muzycznego Takarazuka, a każda nowa inscenizacja tego utworu, których było kilkanaście, przyciągała tłumy widzów.

Wprowadzenie w 1967 roku do repertuaru Teatru Muzycznego Takarazuka znanych na całym świecie musicali Hair oraz Oklahoma! okazało się przełomowym momentem w historii zespołu, wyznaczającym początek intensywnej amerykanizacji. O końcu kilkunastoletniego, naznaczonego głównie wpływami europejskimi okresu świadczą dziesiątki innych amerykańskich musicali, a wśród nich między innymi: West Side Story $(1968)^{40}$, Carousel (1969), Brigadoon (1974), South Pacific (1984), Guys \& Dolls (1984), Show Boat (1986), Me \& My Girl (1987), Kiss Me Kate (1988), Redhead (1988), The Sound of Music (1988), The Apple Tree (1993), Can can (1996), How to Succeed (1996). Z czasem na scenę Teatru Muzycznego Takarazuka trafiły również musicale europejskie, takie jak austriacki Elisabeth (1996) czy francuski Roméo et Juliette: de la Haine à l'Amour (Romeo i Julia: od Nienawiści do Miłości, 2010) czy Le Roi Soleil (Król Słońce, 2014). Wielka popularność musicali sprawiła, że również wszystkie pozostałe sztuki zaczęto aranżować w takiej konwencji.

Trudno więc zaprzeczyć, że Teatr Muzyczny Takarazuka jest teatrem bardzo zwesternizowanym. Większość obecnie wystawianych sztuk określa się mianem yōmono (sztuki w stylu zachodnim). Ich akcja osadzona jest na Zachodzie, a fabuła - oparta na prawdziwych lub fikcyjnych wydarzeniach. Do yōmono zalicza się także reinscenizacje oryginalnych produkcji zachodnich (musicale, opery).

Nader ciekawym aspektem westernizacji stylu Teatru Muzycznego Takarazuka jest wizerunek postaci. O ile bowiem zachowanie bohaterów odpowiada raczej japońskim kanonom, o tyle ich wygląd bliższy jest amerykańskim czy europejskim ideałom. Z tego powodu można odnieść wrażenie, że w wystawianych przez ten teatr sztukach yōmono dochodzi do przeniesienia realiów życia Japończyków na grunt zachodni. Uzyskuje się w ten sposób osobliwy efekt osadzenia japońskiego charakteru i psychiki w ciele obcokrajowca, którego najbardziej „egzotyczną” cechą staje się obcojęzyczne imię. Intryguje zatem kontrast między zachodnim phisis postaci a ich japońską mentalnością - zarówno kobiet, jak i mężczyzn.

Westernizacja dotyczy również tańca. Europejski taniec klasyczny i nowoczesny, tańce latynoamerykańskie pojawiają się niemal w każdym spektaklu. Są nieodłącznym elementem większości sztuk, dramatów i musicali, których akcja toczy się na Zachodzie, a przede wszystkim przedstawień rewiowych. Dlatego nawet gdy pierwszą część (przed przerwą) pełnego programu danego przedstawienia wypełnia sztuka o tematyce japońskiej (zwana nihonmono lub wamono), to w drugiej przewidziana jest zwykle godzinna rewia, dzięki czemu podczas każdego spektaklu można podziwiać także taniec zachodni. Tradycyjne

\footnotetext{
39 Japoński komiks.

${ }^{40}$ Data pierwszego wystawienia na scenie Teatru Muzycznego Takarazuka.
} 
tańce japońskie pojawiają się w rewiach sporadycznie i głównie w celu urozmaicenia, kontrastu lub, ironicznie, jako orientalna ozdoba spektaklu ${ }^{41}$.

Stylowi tańców odpowiada akompaniament. Rozlega się zatem głównie europejska muzyka klasyczna, jazz, disco, rock, country. Zwraca jednak uwagę paradoks: o ile w inscenizacjach sztuk w stylu japońskim oprócz shamisenu ${ }^{42}$ czy koto ${ }^{43}$ pobrzmiewają także zachodnie instrumenty, o tyle w sztukach w stylu zachodnim tradycyjna muzyka japońska należy do rzadkości.

\section{Rodzime tradycje}

Nie można jednak powiedzieć, że Teatr Muzyczny Takarazuka całkowicie oderwał się od korzeni japońskiej tradycji teatralnej. „Japonizacja” zapożyczonych z obcych kultur wzorców nie jest w Japonii ani niczym nowym, ani wyjątkowym, podobnie jak jednoczesna dbałość o rodzime wartości. Styl zespołu jest rezultatem harmonijnego stopienia obu tych tendencji. Należy zatem pamiętać, że wprowadzenie do repertuaru zagranicznych sztuk miało na celu urozmaicenie, a nie całkowite odcięcie się od teatralnej spuścizny własnego kraju. Konwencja zespołu choć wyraźnie odzwierciedla fascynację twórców kulturą Zachodu, niezmiennie pozostaje teatrem typowo japońskim - pod względem artystycznym, społecznym, a przede wszystkim estetycznym. Świadczy o tym na przykład to, że wprawdzie liczba wystawianych rocznie spektakli wamono jest zdecydowanie mniejsza od liczby spektakli yōmono, to nie sposób sobie wyobrazić, żeby w ciągu jednego sezonu nie została wystawiona przynajmniej jedna sztuka wamono. Sztuki takie cieszą się popularnością, ponieważ utrwalają pamięć historyczną, mitologiczną i widowiskową Japończyków.

Uczennice Szkoły Muzycznej Takarazuka, od chwili wstąpienia do niej, są przygotowywane $\mathrm{z}$ jednakową systematycznością i profesjonalnością zarówno do występowania w sztukach typu yōmono, jak i wamono. Oprócz zachodnich technik tanecznych, wokalnych, aktorskich młode adeptki muszą nauczyć się japońskiego tańca (buyō), śpiewu, gry na shamisenie, koto, fue (flecie) czy różnego rodzaju bębnach. Jedynym zaś instrumentem zachodnim, który powinny opanować, jest fortepian ${ }^{44}$.

W przedstawieniach Teatru Muzycznego Takarazuka bez trudu można się doszukać fascynacji kabuki. Związek z tym klasycznym teatrem przejawia się nie tylko w traktowaniu go przez twórców rewii jako artystycznej inspiracji, ale także w realizowaniu razem z aktorami kabuki eksperymentalnych spektakli. Na przykład w sierpniu 2005 roku w Osace Teatr Muzyczny Takarazuka po raz pierwszy w historii nawiązał bezpośrednią współpracę $\mathrm{z}$ teatrem kabuki. Wraz $\mathrm{z}$ aktorami reprezentującymi styl kamigata kabuki ${ }^{45}$, w ramach corocznego przedsięwzięcia promującego młodych aktorów teatru kabuki - Heisei (buyō)

${ }^{41} \mathrm{Z}$ wyjątkiem rewii o tematyce japońskiej, które w całości oparte są na tradycyjnym tańcu japońskim

42 Tradycyjny japoński instrument strunowy przypominający bałałajkę (typ gitary).

43 Tradycyjny japoński instrument strunowy szarpany, rodzaj cytry.

44 Y. Ueda, Takarazuka Ongaku..., op. cit., s. 40-41.

45 Styl kabuki charakterystyczny dla rejonu Kansai. 
Wakashū Kabuki (Kabuki Młodych Mężczyzn ery Heisei), we wspólnie wystawionej sztuce pt. Hanakurabe kabuki emaki (Opowieść o dwóch kwiatach) ${ }^{46}$ wystąpiła wybitna odtwórczyni ról męskich Kiriya Hiromu (ur. 1974) wraz z dziewięcioma innymi aktorkami rewiowymi, w tym również specjalistkami od ról żeńskich. Niezależnie od własnego emploi, wszystkie występujące w tym przedstawieniu artystki Teatru Muzycznego Takarazuka wcieliły się w postaci kobiece, które w kabuki są tradycyjnie wykonywane przez mężczyzn

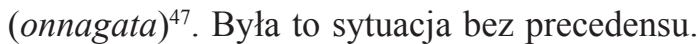

Podobnie Kazuo Hasegawa (1908-1984) ${ }^{48}$, współreżyserujący z Shinjim Uedą (ur. 1933) pierwszą inscenizację Róży Wersalu (1974), szczególną wagę przywiązywał do tego, aby kunszt (waza) artystek rewiowych dorównywał mistrzowskiemu kunsztowi wykonawczemu aktorów teatru kabuki. Hasegawa dostrzegał bowiem wówczas potrzebę udoskonalenia charakterystycznej dla Teatru Muzycznego Takarazuka techniki gry. Uważał, że da się to osiągnąć, wzorując się na technice aktorskiej kabuki. Róża Wersalu to pierwsze przedstawienie, w którym można było podziwiać ewidentne efekty takich starań. Z czasem gra inspirowana częściowo przestrzeganą w kabuki ideą mistrzowską (waza) stała się jedną z podstawowych cech aktorstwa artystek z Takarazuka. Można je rozpoznać na przykład po pinspotto (od ang. pinspot) lub itatsuki (dosłownie: na desce) - podobnym do mie $e^{49}$ pozom. Pinspotto ma służyć zwiększeniu ekspresji danego gestu lub wyrazu twarzy poprzez kilku- lub kilkunastosekundowe zatrzymanie. W trakcie przybrania takiej pozy na aktorkę kierowany jest przykuwający dodatkowo uwagę widza snop białego światła.

Aktorka zastygła w pozie itatsuki ukazuje się oczom widzów, stojąc na zapadni. Jej sylwetkę można zauważyć zwykle bezpośrednio po zmianie dekoracji, rozpoczęciu kolejnego aktu lub w momencie oświetlenia sceny po uprzednim jej zaciemnieniu.

\section{Kiyoku, tadashiku, utsukushiku}

Motto Teatru Muzycznego Takarazuka brzmi: „niewinnie, poprawnie, pięknie” (kiyoku, tadashiku, utsukushiku). Pochodzi ono z wiersza napisanego przez Kobayashiego z okazji otwarcia tokijskiej siedziby zespołu. Obecnie hasło kiyoku, tadashiku, utsukushiku uważa się za podstawowy wyznacznik zasad moralnych. Z motta wynika konieczność wyzbycia się ,wszystkiego, co niestosowne i wulgarne, czyli tego, co niszczy iluzję” (Takarazuka

46 Sztuka z 2005 roku autorstwa pisarza, dramaturga i reżysera teatralnego Satoru Okamoto, w reżyserii aktora kabuki Hidetarō Kataoki.

47 Takarazuka to Kabuki korabokōen, http://www.sponichi.co.jp/osaka/ente/takarazuka/backnumber/050813/ takarazuka.html (23.07.2015).

48 Japoński aktor kabuki. Zasłynął głównie jako aktor filmowy. Grał w ponad dwustu filmach, w tym m.in. w Jüjiro (Skrzyżowanie, 1928), Genji monogatari (Opowieść o Księciu Promienistym, 1951), Chūshingura (Skarbiec wiernych poddanych, 1958) czy Chikamatsu Monogatari (Ukrzyżowani kochankowie, 1954).

${ }^{49}$ Mie - jedna z technik gry aktorskiej w teatrze kabuki. Polega na zastygnięciu aktora w wystylizowanej, ekspresyjnej pozie lub wyrazie twarzy w celu podkreślenia znaczenia danej sceny czy też emocji i charakteru bohatera. Szerzej na ten temat zob.: E. Żeromska, Japoński teatr klasyczny, op. cit., s. 164-165. 
Sumiregumi 191) ${ }^{50}$. Teatr Muzyczny Takarazuka to świat marzeń (yume no sekai) - wyobcowany z niemoralnych i przygnębiających aspektów rzeczywistości ${ }^{51}$.

W imię niewinności, poprawności i piękna na scenie nie pokazuje się między innymi kochanków w sytuacjach intymnych. Tabu dotyczy też nagiego ciała, które, choć obecnie traktowane znacznie mniej rygorystycznie niż przed laty, nadal jest osłaniane cienkim materiałem o odpowiednim kolorze. W sztukach autorskich kwestie budzące wątpliwości pod względem moralnym, zgodnie z zasadą niewinności, poprawności i piękna, są albo celowo pomijane, albo tylko powierzchownie sygnalizowane, a w przypadku reinscenizacji oryginalnych sztuk zachodnich - zmieniane lub wręcz usuwane ${ }^{52}$.

Częstym tematem spektakli prezentowanych na scenie Teatru Muzycznego Takarazuka są perypetie charakterystyczne dla tak zwanych ningen dorama (sztuk obyczajowych), popularnych również we współczesnych japońskich serialach telewizyjnych. Są to utwory skupiające się na codziennych zmaganiach i relacjach międzyludzkich, często opowiadające o przyjaźni, miłości, zemście czy nienawiści. Jest jednak również wiele utworów bogatych w podteksty edukacyjne i moralizujące ${ }^{53}$. Na przykład głównym bohaterem wystawionej w 2008 roku sztuki pt. $A-$ " $R$ ”ex jest Aleksander Macedoński. Tymczasem zarówno z kostiumów, jak i z dialogów wynika dwuwarstwowość, ponieważ autor, Kōichi Ogita, wprowadza aluzje do polityki USA lat siedemdziesiątych XX wieku, umiejętnie wykorzystując w tym celu rozterki króla Macedonii. Podobnie Keiko Ueda (ur. 1966) w Kurashiko Itariāno (Włoska klasyka, 2012) opowiada między innymi interesującą historię męskiego garnituru, a zarazem skłania do refleksji nad tradycją i nowoczesnością, nawiązując do problemu podtrzymania tradycyjnego rzemiosła w obliczu postępującej modernizacji i galopującego konsumpcjonizmu.

Teatr Muzyczny Takarazuka jest bez wątpienia jednym z najprężniej działających japońskich teatrów współczesnych, powstałych w XX wieku. Każdego roku odwiedza go 2,5 miliona widzów ${ }^{54}$, a Klub Przyjaciół Takarazuka (Takarazuka-tomo no Kai), oficjalny fanklub, skupia ponad 70 tysięcy członków ${ }^{55}$. Mimo to status tego zespołu w kraju i na świecie stale pozostaje niejasny. Wynika to najprawdopodobniej z jego pierwotnie artystyczno-komercyjnego charakteru oraz z traktowania go, nawet przez założyciela, jako towaru na sprzedaż ${ }^{56}$, co w konsekwencji trwałe zdeterminowało też styl rewii - styl z pogranicza sztuki wysokiej i niewybrednej rozrywki. Paradoksalnie właśnie owo harmonijne połączenie trendów kultury masowej z japońską i zachodnią tradycją, prostoty z przepychem, kiczu z wyrafinowaniem tworzy unikalny styl zespołu Takarazuka.

50 Takarazuka Sumiregumi, Takarazuka daijiten, Tōkyō 2000, s. 191.

${ }^{51}$ Kawasaki K., Takarazuka to iu yūtopia, op. cit., s. 169.

52 Ibidem.

${ }^{53}$ K. Nimiya, Takarazuka no kōki - Osukaru kara posuto feminizumu he, Tōkyō 1995, s. 23.

54 Hankyū Hanshin Holdings, Annual Report 2013, http://holdings.hankyu-hanshin.co.jp/ir/library/annualreports/data/131.pdf (20.07.2015).

55 Takarazuka to fan (jō), http://www.sankei.com/west/news/140803/wst1408030046-n1.html (29.07.2015).

56 Ō. Kōbō, Takarazuka! Kore zo entāteinmento, Tōkyō 2001, s. 76. 


\section{Bibliografia}

Hankyū Hanshin Holdings, Annual Report, 2013, <http://holdings.hankyu-hanshin.co.jp/ir/library/ annualreports/data/131.pdf> (20.07.2015).

Hosokawa S., Shoki no Takarazuka Kageki bunkashi - otogigeki kara rebyū made, ed. B. Makita, $<$ http://web.kyoto-inet.or.jp/people/vmakita/ezuka-speech.html> (25.07.2015).

Kawasaki K., Takarazuka to iu yūtopia, Tōkyō 2005.

Kawasaki K., Takarazuka shōhishakai no supekutakuru, Tōkyō 1999.

Kobayashi I., Takarazuka manpitsu, Tōkyō 1980.

Kobayashi I., Watakushi no yukikata, Tōkyō 2006.

Kobayashi K., Prelude - Takarazuka Ongaku Gakkō dai 93ki Bunkasai, Takarazuka 2007.

Kōbō Ō., Takarazuka! Kore zo entāteinmento, Tōkyō 2001.

Nimiya K., Takarazuka no kōki - Osukaru kara posuto feminizumu he, Tōkyō 1995.

Shima O., Kobayashi Ichizō to sono bijogun, 70 nen no himitsu - Za Takarazuka, Tōkyō 1984.

Sugawara M., Yume no rebyūshi, Tōkyō 1996.

Takarazuka Sumiregumi, Takarazuka daijiten, Tōkyō 2000.

Takarazuka to fan (jō), <http://www.sankei.com/west/news/140803/wst1408030046-n1.html> (29.07.2015).

Takarazuka to Kabuki korabokōen, 2005, <http://www.sponichi.co.jp/osaka/ente/takarazuka/backnumber/050813/takarazuka.html> (23.07.2015).

Tsuganesawa T., Takarazuka Senryaku - Kobayashi Ichizō no seikatsubunkaron, Tōkyō 1991.

Ueda Y., Takarazuka Ongaku Gakkō, Ōsaka 1976.

Watanabe H., Takarazuka Kageki no henyō to Nihon kindai, Tōkyō 1999.

Yume wo egaite hanayaka ni Takarazuka Kageki 80 nenshi, Takarazuka 1994.

Żeromska E., Japoński teatr klasyczny. Korzenie i metamorfozy, t. 2: Kabuki, burnaku, Warszawa 2009.

Żeromska E., Na pograniczu realizmu: kobieta i kobiecość w teatrze japońskim, Porównania 2016, nr 18, s. 239-256.

\section{MONIKA LECIŃSKA-RUCHNIEWICZ}

\section{A historical overview of the Takarazuka musical theatre - in search of a new ,national theatre".}

Summary

The Takarazuka Revue (Takarazuka Kagekidan) occupies an important place among Japanese modern theatres and enjoys unwavering popularity both in Japan and abroad. Both the artistic and commercial character of the idea that brought the first Japanese all-female revue to life in 1914 determined its further development and process of conversion from a simple choir to a full scale musical theater. Kobayashi - the founder of the Takarazuka Revue, an opera aficionado and theater critic - was driven by the need to create a new, affordable and easily understandable national theater that would meet the needs of modern Japanese society. Currently, the Takarazuka Revue is one of the most active and successful modern Japanese theaters. Its harmonious combination of trends in mass culture and Japanese and Western theatrical traditions is fascinating. The highly characte- 
ristic fusion of simplicity and splendour, kitsch and sophistication that can be seen in the revue's works, creates a unique, albeit somewhat controversial style, complemented by musumeyaku (female emploi) i otokoyaku (male emploi) played by actresses taught in a special school affiliated to the Takarazuka Revue.

Keywords: Takarazuka Revue, Japanese theatre, entertainment, musical, mass culture, modernization 